\title{
Peran Media Massa dalam Meningkatkan Partisipasi Politik Para Aktivis HMP PKn di Yogyakarta
}

\author{
DIAH NOVIANASARI, SAMSURI \\ Jurusan Pendidikan IPS Program Pascasarjana, Universitas Negeri Yogyakarta \\ Email : diah.novianasari@yahoo.co.id, samsuri@uny.ac.id
}

\begin{abstract}
Abstrak
Penelitian ini bertujuan untuk mengetahui: (1) peran media massa dalam meningkatkan partisipasi politik para aktivis HMP PKn di Yogyakarta; (2) faktor yang mendorong peran media massa dalam meningkatkan partisipasi politik para aktivis HMP PKn di Yogyakarta; (3) faktor yang menghambat peran media massa dalam meningkatkan partisipasi politik para aktivis HMP PKn di Yogyakarta. Penelitian ini menggunakan pendekatan deskriptif kualitatif naturalistik yang dilaksanakan di HIMA PKnH UNY, HMP PPKn UPY, dan HMPS PPKn UAD. Informan dalam penelitian ini yaitu para aktivis HMP PKn di Yogyakarta yang diambil dengan teknik purposive. Hasil penelitian ini menunjukkan bahwa: (1) peran media massa dalam meningkatkan partisipasi politik para aktivis HMP PKn di Yogyakarta mengarah pada tipe gerakan moral dan tipe budaya politik partisipan; (2) faktor pendorongnya meliputi: kebutuhan perkuliahan dan kesadaran diri para aktivis; (3) faktor penghambatnya meliputi: keterbatasan kebebasan berpendapat, keterbatasan keterbacaan tulisan, keefektifan kerja nyata di HMP PKn, kepadatan aktivitas kampus, dan keterbatasan publikasi melalui media koran.
\end{abstract}

Kata Kunci : Partisipasi Politik, Media Massa, dan Aktivis Organisasi Kemahasiswaan

\section{Abstract}

This research aims to find out: (1) the role of mass media to increase political participation of activists of HMP PKn in Yogyakarta; (2) factors that support the role of mass media to increase political participation of activists of HMP PKn in Yogyakarta; (3) factors that inhibit the role of mass media to increase political participation of activists of HMP PKn in Yogyakarta. This research is a naturalistic qualitative descriptive research. This research was conducted in HIMA PKnH UNY, HMP PPKn UPY, and HMPS PPKn UAD. The subjects of this research are activists of HMP PKn in Yogyakarta who were taken with purposive sampling techniques. The result of this research shows that: (1) the role of mass media to increase political participation of activists of HMP PKn in Yogyakarta that aims to the moral movement type and the participant political culture type; (2) the supporter factors include: requirements of lectures and awareness as good citizens; (3) the inhibitor factors include: freedom to give opinion is unsecured, the written is rarely readable, the participation with real work in HMP PKn is considered more effective than writing opinions in mass media, the business of campus activities, and publication process that is quite limited in newspapers.

Keywords : Political Participation, Mass Media, and Activists of Student Organization 


\section{PENDAHULUAN}

Indonesia merupakan salah satu negara di dunia yang berasaskan demokrasi. Demokrasi merupakan asas negara yang berupaya memegang tinggi prinsip kebebasan. Setiap orang memiliki kebebasan dan kesetaraan dalam menentukan kondisi kehidupanya dan memperoleh hak serta kewajiban yang sama. Menurut Sorensen (2003, p.15), demokrasi membutuhkan pernyataan hak-hak manusia (bill of right) di luar hak memilih untuk memberikan kesempatan yang sama untuk berpartisipasi dan untuk menemukan preferensi pribadi dan pengawasan akhir oleh warga negara terhadap agenda politik. Berdasarkan penjabaran Sorensen tersebut, dapat dipahami bahwa ternyata kebebasan itu merupakan serangkaian hak bagi seluruh warga negara untuk berpartisipasi aktif dalam politik.

Setiap warga negara Indonesia memiliki hak yang sama untuk mengemukakan pendapat sebagaimana yang tercantum dalam Pasal 28E Ayat (3) Undang-Undang Dasar 1945, yang menyatakan bahwa setiap orang berhak atas kebebasan berserikat, berkumpul, dan mengeluarkan pendapat. Hak warga negara dalam hal kemerdekaan berserikat dan berkumpul, mengeluarkan pikiran tersebut dapat dilakukan baik secara lisan, tulisan dan sebagainya. Pasal ini memberikan penguatan bahwa setiap warga negara memiliki hak yang sama, yaitu hak untuk berpartisipasi aktif dalam menyampaikan pendapat atau opini politik baik lisan maupun tulisan, baik yang berhubungan dengan kinerja maupun yang berhubungan dengan permasalahan pribadi para pejabat pemerintah.

Seluruh perguruan tinggi di Yogyakarta bahkan di seluruh Indonesia berupaya memberikan kesempatan yang seluas-luasnya bagi para mahasiswa untuk membentuk sebuah komunitas, perkumpulan, ataupun organisasi sebagai wadah pembelajaran pengembangan diri dan sarana menghimpun aspirasi para mahasiswanya. Melalui organisasi yang diikuti, mahasiswa sebagai anggota kelompok dapat memperoleh banyak pengalaman dan pembelajaran. Seperti misalnya, pengalaman berinte- raksi sosial, mengenal beragam kepribadian, mengenali kepribadian diri sendiri, belajar mengatasi berbagai masalah, belajar berpikir kritis, belajar mengelola waktu, belajar berbicara di depan banyak orang, penuh inisiatif, dan keberanian mengemukakan pendapat pribadi dan buah pikir yang dimiliki.

Mahasiswa sebagai bagian dari masyarakat akademik dituntut untuk memiliki kepribadian sebagai warga negara yang tangguh dan kuat. Kepribadian tersebut terutama berkaitan dengan peran mahasiswa sebagai agent of change atau agen perubahan. Kemampuan untuk berpartisipasi politik wajib dimiliki oleh setiap mahasiswa. Kemampuan ini akan mendukung para mahasiswa dalam menjalankan tugas sebagai agen perubahan. Mahasiswa harus mampu berpikir kritis dan bertindak efektif dalam menanggapi segala persoalan yang dihadapi bangsa ini. Mahasiswa harus mampu menjadi insan yang cerdas dan memiliki banyak pengetahuan. Media massa, seperti media televisi, internet, dan surat kabar merupakan media komunikasi yang dekat dengan masyarakat. Ketiga media ini telah menjadi bagian penting dalam keseharian mahasiswa di Yogyakarta. Melalui media cetak dan elektronik ini, mahasiswa dapat memperoleh berbagai informasi termasuk yang berkaitan dengan kondisi politik di Indonesia. Mahasiswa dapat dengan mudah menyaksikan berbagai aktivitas pemerintah, hasil kinerja, dan lain sebagainya melalui berbagai media massa. Melalui informasi yang diperoleh dari berbagai media massa, mahasiswa dapat memperoleh gambaran mengenai kondisi politik di Indonesia sehingga dapat memberikan penilaian dan menentukan tindakan yang dianggap paling tepat atas permasalahan politik yang sedang terjadi.

Pejabat pemerintah harus mampu mengemban amanah yang diberikan seluruh rakyat Indonesia. Pemerintah memiliki tanggung jawab yang besar berkaitan dengan kelangsungan bangsa dan negara ini. Harapan ini berbanding terbalik dengan kenyataan yang kini sedang terjadi di Indonesia. Tidak sedikit pejabat pemerintah, seperti misalnya para wakil rakyat yang berasal dari beberapa 
partai besar di Indonesia terpaksa meninggalkan kursi jabatannya karena tersandung kasus korupsi. Tidak hanya para wakil rakyat saja, tetapi para petinggi partai juga mengulangi kesalahan yang sama karena terbukti melakukan penyalahgunaan wewenang atau korupsi yang tentu saja menyakiti dan mengecewakan rakyat Indonesia. Berbagai permasalahan tersebut disebarluaskan dan diinformasikan kepada mahasiswa melalui berbagai media massa. Mahasiswa yang aktif mengikuti perkembangan informasi akan mampu berpikir kritis sehingga tergugah untuk melakukan tindakan efektif sebagai bentuk respon terhadap permasalahan publik yang sedang terjadi. Oleh sebab itu, maraknya berbagai kasus penyalahgunaan wewenang yang dilakukan oleh pemerintah Indonesia saat ini masih memerlukan lebih banyak lagi kontrol dari mahasiswa sebagai agen perubahan melalui berbagai macam tindakan.

Lubis (2013, p.69), menekankan teramat penting bagi seluruh manusia Indonesia (tidak hanya mahasiswa saja) untuk meningkatkan sebesar-besarnya kemampuan untuk mengikuti, memahami sebaik-baiknya seluruh perkembangan dan perubahan yang sedang terjadi di Indonesia bahkan di dunia, termasuk berbagai perubahan-perubahan yang bersifat kemasyarakatan dan nilai-nilai serta pikiran manusia, sehingga masyarakat Indonesia termasuk mahasiswa dapat menghasilkan persepsi di bidang sosial, ekonomi, dan politik yang dapat membawa perubahan menuju arah dan kondisi bangsa dan negara yang lebih baik.

Protes atau opini mahasiswa terkait berbagai kasus penyalahgunaan dapat disampaikan kepada berbagai pihak yang berkepentingan melalui sebuah gerakan atau aksi protes yang dilakukan oleh para mahasiswa. Gerakan atau aksi protes merupakan perwujudan dari tugas mahasiswa sebagai agent of change atau agen perubahan yang bertujuan untuk megubah sebuah kebijakan yang tidak pro rakyat menjadi sangat berpihak pada rakyat atau dengan kata lain sebagai usaha memperjuangkan kepetingan rakyat. Oleh sebab itu, mahasiswa menjadi salah satu pilar demokrasi yang menjunjung tinggi hak rakyat untuk memperoleh keadilan. Namun, ternyata harapan ini tidak sejalan dengan kondisi yang sedang terjadi saat ini.

Berbagai gerakan dan aksi protes para mahasiswa kini tidak mampu lagi menarik simpati rakyat karena banyak terjadi aksi protes yang justru berakhir ricuh, mengganggu ketertiban, dan tidak jarang bermuatan politik sehingga menimbulkan ketidakstabilan sosial dan keamanan seperti rasa takut dan kerugian materiil yang cukup besar yang disebabkan karena kerusuhan yang dilakukan oleh para mahasiswa. Matulessy (2008, p.4), menganalisis tentang model kausal partisipasi politik aktivis gerakan mahasiswa yang dilakukan pada tahun 2008, menyatakan bahwa gerakan partisipasi mahasiswa lebih banyak berujung pada tindakan anarkis ternyata didominasi oleh deprivasi relatif atau ketidakpuasan baik yang bersifat dorongan individual maupun dorongan kolektif semisal organisasi kemahasiswaan yang kurang terkendali. Hal ini mengindikasikan bahwa aksi demonstrasi tidak selalu dianggap tepat untuk menjadi sarana partisipasi politik para mahasiswa.

Gerakan mahasiswa ternyata tidak hanya sebatas yang bisa dilakukan dalam wujud demonstrasi saja, namun dapat pula dilakukan melalui pemanfaatan media massa yang dinilai lebih santun dibandingkan dengan aksi demonstrasi yang berujung keributan. Penyampaian opini terkait berbagai permasalahan publik yang dilakukan melalui berbagai media massa dinilai jauh lebih santun. Hal ini disebabkan karena untuk bisa menulis diperlukan kemampuan berbahasa yang baik serta hendaknya memiliki etika beropini yang baik pula sehingga tidak menimbulkan pro dan kontra bagi pembacanya.

Secara umum, media massa memiliki peran sebagai sumber informasi dan sarana partisipasi warga negara. Melalui perkembangan media masssa yang cukup pesat saat ini, maka mahasiswa memiliki kesempatan yang besar untuk memanfaatkan berbagai media massa untuk mendukung berbagai aktivitas termasuk sebagai sarana partisipasi politik melalui penyampaian berbagai opini terkait 
berbagai permasalahan publik dengan menggunakan berbagai media massa yang telah tersedia serta dapat dimanfaatkan dengan mudah. Pemberitaan di media massa memiliki kemampuan untuk mempengaruhi kognisi seseorang, kognisi akan mengarahkan pada afeksi, dan afeksi akan mendorong seseorang untuk melakukan sebuah tindakan. Tindakan ini dapat direalisasikan pula dengan memanfaatkan media massa, sehingga media massa memiliki fungsi ganda sebagaimana yang telah diungkapkan sebelumnya. Inilah sebabnya, media massa memiliki peran yang sangat penting bagi para penggunanya.

Mahasiswa Program Studi PKn secara teoretis merupakan kaum intelektual yang seharusnya mampu berpartisipasi secara aktif bagi kelangsungan demokrasi dalam kehidupan berbangsa dan bernegara. Menurut John Patrick sebagaimana yang dikutip Samsuri (2012, p.56), menyatakan bahwa terdapat empat komponen atau ketegori pokok yang hendaknya dipahami bahkan dikuasai oleh para pendidik atau calon pendidik PKn, keempat komponen tersebut, yaitu: (1) pengetahuan kewarganegaraan dan pemerintahan demokratis, (2) kecakapan kognitif dari kewarganegaraan demokratis, (3) kecakapan partisipasi dari kewarganegaraan demoratis, dan (4) keutamaan karakter kewarganegaraan yang demokratis. Hal ini menunjukkan bahwa mahasiswa Program Studi PKn merupakan sosok yang hendaknya tidak hanya unggul secara kognisi saja tetapi juga unggul secara afeksi dan psikomotorik, sehingga mampu menjadi warga negara yang kritis dan mampu berperan aktif mengawal proses demokrasi yang terjadi di negaranya.

Pendapat atau opini yang disampaikan melalui berbagai cara dan media sebagai salah satu bentuk partisipasi politik mahasiswa membutuhkan cukup keberanian, motivasi, serta kesadaran yang tinggi untuk melakukannya. Mahasiswa dapat memperoleh banyak pengetahuan dan sarana pengembangan diri di perguruan tinggi. Salah satunya yaitu melalui organisasi kemahasiswaan Himpunan Mahasiswa Program Studi Pendidikan Kewargane- garaan (HMP PKn). Organisasi Kemahasiswaan HMP PKn dapat membantu mahasiswa pada Program Studi PKn, terutama para aktivis HMP PKn itu sendiri dalam mengasah keberanian, memperoleh dorongan motivasi, dan memupuk kesadaran atas hak dan kewajiban para anggotanya sebagai warga negara terhadap negaranya.

Penyampaian berbagai opini melalui berbagai media massa yang dilakukan oleh para mahasiswa Program Studi PKn terutama para aktivis dari organisasi kemahasiswaan tersebut terkait berbagai permasalahan publik tidak dapat dilepaskan dari kecenderungan tipe gerakan partisipasi dan tipe budaya politiknya. Hal ini menjadi sangat penting diketahui sebab dengan melihat kecenderungan tipe gerakan dan tipe budaya politiknya, maka dapat diketahui kualitas dan tingkat partisipasi politiknya. Mahasiswa PKn sebagai sosok yang dianggap paling mampu berpartisipasi idealnya memiliki tipe partisipasi politik yang unggul dan sebab kepemilikan tipe gerakan politik dan tipe budaya politik yang unggul menunjukkan bahwa pelakukanya merupakan warga negara yang baik yang mampu berpartisipasi dan berperan serta secara maksimal sebagai warga negara yang baik.

Oleh sebab itu, sangat penting untuk dilakukan penelitian secara lebih mendalam mengenai: (1) Bagaimana peran media massa dalam meningkatkan partisipasi politik para aktivis HMP PKn di Yogyakarta? (2) Apa faktor yang mendorong peran media massa dalam meningkatkan partisipasi politik para aktivis HMP PKn di Yogyakarta? (3) Apa faktor yang menghambat peran media massa dalam meningkatkan partisipasi politik para aktivis HMP PKn di Yogyakarta? Melalui penelitian ini, diharapkan mampu memberikan manfaat dan kontribusi terkait pentingnya peran media massa dalam meningkatkan partisipasi politik para aktivis HMP PKn di Yogyakarta.

\section{METODE \\ Jenis Penelitian}

Penelitian ini menggunakan metode penelitian deskriptif kualitatif dengan menggu- 
nakan pendekatan naturalistik, sebab kondisi nyata yang terjadi di lapangan merupakan data yang paling bisa diterima. Melalui pemilihan metode penelitian kualitatif, maka penelitian ini berusaha mendeskripsikan dan menganalisis secara mendalam mengenai peran media massa dalam meningkatkan partisipasi politik para aktivis HMP PKn di Yogyakarta. Hal ini dipilih untuk memperoleh hasil penelitian yang lebih lengkap dan mendalam. Hasil penelitian yang berwujud deskripsi diharapkan dapat lebih mudah dipahami oleh para pembaca dan pengguna hasil penelitian ini.

\section{Waktu dan Tempat Penelitian}

Penelitian ini dilaksanakan di HIMA PKnH UNY, HMP PPKn UPY, dan HMPS PPKn UAD pada bulan April hingga Juni 2014. Penelitian ini mengambil UNY, UPY, dan UAD sebagai lokasi penelitian sebab ketiganya ini selain dapat mewakili basis dan status perguruan tinggi yang memiliki Program Studi PKn di Yogyakarta, namun juga karena memiliki berbagai sarana yang dapat mendukung hasil penelitian ini.

\section{Subjek Penelitian}

Pada penelitian mengenai peran media massa dalam meningkatkan partisipasi politik para aktivis HMP PKn di Yogyakarta ini, informan yang dipilih tidak hanya yang memenuhi karakteriktik seorang aktivis HMP PKn saja, hendaknya memiliki pengetahuan yang cukup serta mampu menjelaskan keadaan tentang objek penelitian untuk menjawab permasalahan yang diangkat. Teknik penentuan informan penelitian yang digunakan yaitu teknik purposive. Peneliti menjadikan 5 aktivis HIMA PKnH UNY, 5 aktivis HMP PPKn UPY, dan 5 aktivis HMPS PPKn UAD sehingga seluruhnya berjumlah 15 informan atau subjek penelitian.

\section{Teknik dan Istrumen Pengumpulan Data}

Pada penelitian kualitatif, instrumen pengumpulan data adalah peneliti sendiri sebagaimana yang diungkapkan Creswell (2012, pp.264-265), bahwa penelitian kualitatif merupakan penelitian interpretatif sehingga peneliti tidak hanya sebagai pelapor hasil penelitian saja, tetapi juga terlibat dalam pengalaman yang berkelanjutan dan terus menerus dengan partisipan. Oleh sebab itu, teknik dan instrumen pengumpulan data dalam penelitian mengenai peran media massa dalam meningkatkan partisipasi politik para aktivis Himpunan Mahasiswa Program Studi Pendidikan Kewarganegaraan di Yogyakarta ini, secara lebih lengkap adalah sebagai berikut:

\section{Observasi Partisipan}

Peneliti secara langsung maupun tidak langsung ikut serta dalam kegiatan-kegiatan mahasiswa terkait dengan penelitian ini, misalnya turut serta dalam kegiatan-kegiatan HMP PKn terutama berkaitan dengan pemanfaatan media massa untuk memperoleh gambaran yang dapat mendukung hasil penelitian ini. Semua ini peneliti lakukan untuk memperoleh berbagai gambaran peran media massa dalam meningkatkan partisipasi politik dalam diri para aktivis HMP PKn tersebut. Instrumen yang digunakan dalam observasi ini yaitu berupa lembar observasi.

\section{Wawancara Tidak Terstruktur}

Wawancara tidak terstruktur atau wawancara mendalam dilakukan untuk mendapatkan lebih banyak informasi tentang peran media massa dalam meningkatkan partisipasi politik para aktivis HMP PKn di Yogyakarta. Wawancara akan dilakukan terhadap 15 aktivis HMP PKn yang diambil dari ketiga perguruan tinggi di Yogyakarta, yaitu dari HIMA PKnH UNY, HMP PPKn UPY, dan HMPS PPKn UAD. Instrumen yang digunakan dalam wawancara ini yaitu berupa pedoman wawancara yang kemudian akan dikembangkan melalui wawancara mendalam.

\section{Dokumentasi}

Dokumentasi yang digunakan untuk mendukung penelitian ini yaitu berupa dokumen-dokumen baik yang bersifat publlik atau resmi maupun yang bersifat privat atau pribadi yang berkenaan dengan pemanfaatan berbagai media massa oleh para aktivis HMP PPKn di Yogyakarta. Dokumen publik atau resmi yang digunakan dalam penelitian ini terdiri atas: berbagai opini yang ditulis oleh para aktiv- 
is HMP PKn di Yogyakarta yang berhubungan dengan objek penelitian ini yang telah dipublikasikan melalui berbagai media massa dan petisi yang pernah dibuat oleh para aktivis HMP PKn di Yogyakarta tentang keadaan dan aturan yang dapat mendukung hasil penelitian ini. Sedangkan dokumen privat atau pribadi yang digunakan dalam penelitian ini terdiri atas berbagai opini yang ditulis oleh para aktivis HMP PKn di Yogyakarta yang berhubungan dengan objek penelitian ini yang belum dipublikasikan sehingga masih bersifat privat.

Berbagai dokumen tersebut digunakan untuk mendukung hasil penelitian, didukung pula dengan foto-foto yang menggambarkan tentang aktivitas pemanfaatan media massa para aktivis HMP PKn di Yogyakarta. Instrumen yang digunakan dalam dokumentasi ini yaitu berupa lembar dokumentasi.

\section{Teknik Analisis Data}

Teknik analisis data dalam penelitian ini dilakukan dengan menggunakan model analisis interaktif seperti yang diungkapkan oleh Miles \& Huberman (1994, pp.10-12), yaitu proses analisis yang dilakukan bersamaan dengan proses pengumpulan data. Proses analisis ini melalui empat tahapan yaitu sebagai berikut:

\section{Pengumpulan Data}

Data yang diperoleh dari hasil observasi, wawancara, dan dokumentasi dicatat dalam catatan lapangan yang terdiri dari dua aspek yaitu deskripsi dan refleksi. Catatan deskripsi merupakan data alami yang berisi tentang apa yang dilihat, didengar, dirasakan, disaksikan, dan dialami sendiri oleh peneliti tanpa adanya pendapat dan penafsiran dari peneliti tentang fenomena yang dijumpai. Sedangkan catatan refleksi yaitu catatan yang memuat kesan, komentar dan tafsiran peneliti tentang temuan yang dijumpai dan merupakan bahan rencana pengumpulan data untuk tahap berikutnya.

\section{Reduksi Data}

Reduksi data merupakan proses seleksi, pemfokusan, penyederhanaan, dan abstraksi. Cara mereduksi data adalah dengan melakukan seleksi, membuat ringkasan atau uraian singkat, menggolongkan ke pola-pola dengan membuat transkip penelitian untuk mempertegas, memperpendek, membuat fokus, membuang bagian yang tidak penting dan mengatur agar dapat menarik kesimpulan.

\section{Penyajian Data}

Penyajian data merupakan sekumpulan informasi yang tersusun sehingga memberikan kemungkinan untuk menarik kesimpulan dan pengambilan tindakan. Agar sajian data tidak menyimpang dari pokok permasalahan maka sajian data dapat diwujudkan dalam bentuk matriks, jaringan, atau bagan sebagai wadah bantuan informasi tentang hal yang terjadi, kemudian data disajikan sesuai dengan apa yang diteliti.

\section{Penarikan Kesimpulan}

Penarikan kesimpulan merupakan usaha untuk mencari atau memahami makna, keteraturan pola-pola penjelasan, alur sebab akibat atau proposisi. Kesimpulan yang diambil segera diverifikasi dengan cara melihat dan mempertanyakan kembali sambil melihat catatan dilapangan agar memperoleh pemahaman yang lebih tepat. Selain itu juga dapat dilakukan dengan mendiskusikannya. Hal tersebut dilakukan agar data yang diperoleh dan ditafsirkan memiliki validitas, sehingga kesimpulan yang diambil menjadi kuat.

\section{HASIL DAN PEMBAHASAN}

Peran Media Massa dalam Meningkatkan Partisipasi Politik para Aktivis HMP PKn di Yogyakarta :

Berdasarkan hasil penelitian yang telah dilakukan di HMP PKn di Yogyakarta, menunjukkan bahwa media televisi, media internet, dan media surat kabar cetak telah dapat dimanfaatkan dengan baik oleh para aktivis HMP PKn di Yogyakarta baik sebagai sumber informasi maupun sebagai sarana partisipasi politik. Hal ini nampak dari hasil observasi, wawancara, dan bukti dokumentasi yang diperoleh selama penelitian ini dilaksanakan di HIMA PKnH UNY, HMP PPKn UPY, dan HMPS PPKn UAD sebagai lokasi penelitian. Media televisi, media internet, dan media surat kabar cetak telah tersedia di lokasi penelitian sehingga dapat dengan 
mudah dimanfaatkan para aktivis HMP PKn di Yogyakarta.

Menurut Junaedi (2013, p.49), partisipasi politik dalam bentuk penyampaian opini atau pendapat terkait berbagai permasalahan yang melanda bangsa dan negara sangat ditentukan terutama oleh media massa. Peran media massa dalam meningkatkan partisipasi politik para aktivis Himpunan Mahasiswa Program Studi Pendidikan Kewarganegaraan (HMP PKn) di Yogyakarta dapat dibedakan menjadi dua, dengan merujuk teori Gazali (2004, p.67), dua fungsi utama tersebut, yaitu: pertama, media massa sebagai media informasi, dan pengetahuan bagi mahasiswa dan kedua, media massa sebagai media partisipasi politik bagi mahasiswa. Melalui berbagai media massa yang dihadirkan, masyarakat dapat mengirim dan menerima pesan, sehingga terjadi interaksi yang bebas dan rasional.

Oleh sebab itu, Gazali (2004, p.54) menyimpulkan bahwa terdapat hubungan yang signifikan antara politik dengan media, sebab media tidak hanya mampu menyampaikan berbagai informasi yang harus diketahui oleh khalayak saja, namun media massa juga mampu mempengaruhi sikap, opini, dan keyakinan individu mengenai proses-proses politik, kekuasaan, dan legitimasi melalui berbagai pemberitaan yang disampaikannya. Peran media massa baik sebagai sumber informasi maupun sebagai sarana partisipasi politik yang telah mampu diimplementasikan oleh para aktivis HMP PKn di Yogyakarta tidak terjadi begitu saja, namun ternyata keduanya memiliki hubungan yang sangat erat. Media massa memiliki kekuatan untuk mempengaruhi opini publik Indonesia.

Berkaitan dengan hal tersebut, Thomas (2009, p.112) dan Yuniati (2002, p.85), menyatakan hal yang sama bahwa media massa mempunyai pengaruh yang sangat kuat dalam pembentukan kognisi seseorang. Media memberikan informasi dan pengetahuan yang pada akhirnya dapat membentuk persepsi. Persepsi ini menjadi patokan dari sebuah tindakan seperti misalnya tindakan pengungkapan opini maupun kritikan ataupun persepsi sebagai respon aktif terhadap berbagai permasalahan publik.

Hal inilah yang juga dialami oleh para aktivis HMP PKn di Yogyakarta. Secara umum, media massa yang ditunjuk dalam penelitian ini terdiri atas tiga macam, yaitu media televisi, internet, dan surat kabar. Berdasarkan hasil penelitan, diketahui bahwa pemanfaatan media massa sebagai sumber informasi telah banyak dilakukan oleh para aktivis HMP PKn di Yogyakarta. Informasi yang yang paling banyak digali yaitu informasi seputar kasus korupsi yang menjerat para pejabat negara semisal kasus MK, perkembangan politik seputar pemilihan umum (pemilu) 2014 baik pemilu legislatif maupun pemilu presiden dan wakil presiden serta berbagai pemberitaan lain seputar perkembangan kurikulum 2013 dan isu kewajiban PPG, dan pemberitaan yang juga tidak kalah menarik yaitu pemberitaan terkait permasalahan sosial seperti kasus pelecehan seksual yang terjadi di beberapa sekolah internasional di Jakarta. Pemberitaan seputar pemilu 2014 merupakan pemberitaan yang paling banyak diminati oleh para aktivis HMP PKn di Yogyakarta.

Para aktivis HMP PKn di Yogyakarta cenderung menghabiskan waktu luang mereka di ruang HMP PKn untuk melakukan berbagai aktivitas. Salah satunya yaitu memanfaatkan media internet untuk mencari berbagai informasi yang dibutuhkan sebagaimana yang telah diungkapkan sebelumnya dengan mengakses berbagai surat kabar online terutama detik.com dan kompasiana.com serta melalui berbagai blog yang ditulis oleh para blogger. Keduanya merupakan surat kabar online yang paling diminati oleh para aktivis HMP PKn di Yogyakarta. Selain memanfaatkan berbagai surat kabar online, para aktivis juga menggunakan berbagai media sosial seperti facebook dan twitter untuk mengetahui berbagai informasi melalui up date status yang ditulis oleh rekan-rekan mereka di akun pribadi masing-masing. Selain media internet, para aktivis HMP PKn di Yogyakarta juga aktif memanfaatkan media televisi sebagai sumber informasi. Channel televisi yang paling banyak diminati yaitu TVOne dan MetroTV. 
Media surat kabar cetak juga mampu memberikan berbagai informasi di samping media televisi dan internet. Berdasarkan hasil penelitian yang telah dilaksanakan di ketiga perguruan tinggi tersebut, diketahui bahwa media surat kabar cetak cenderung jarang dimanfaatkan oleh para aktivis HMP PKn di Yogyakarta. Sebagaimana yang telah diuraikan sebelumnya, kini telah tersedia surat kabar online sehingga menyebabkan para aktivis cenderung mencari informasi melalui berbagai surat kabar tersebut dibanding dengan penggunaan surat kabar cetak. Meskipun demikian, para aktivis HMP PPKn UPY masih tetap memanfaatkan media surat kabar cetak sebagai sumber informasi utama di samping pemanfaatan media TV dan internet karena media massa semacam ini seperti Merapi, Kedaulatan Rakyat, Bernas, dan Media Indonesia, telah disediakan oleh kampus sehingga dapat dimanfaatkan dengan mudah.

Hal ini menunjukkan bahwa media massa yang paling banyak dimanfaatkan sebagai sumber informasi terkait perkembangan berbagai pemberitaan politik, sosial, hukum, ekonomi, dan pendidikan oleh para aktivis HMP PKn di Yogyakarta yaitu media internet (dimanfaatkan oleh para aktivis HIMA PKnH UNY, HMP PPKn UPY, dan HMPS PPKn UAD) terutama detik.com dan kompasiana.com, kemudian media televisi (dimanfaatkan oleh para aktivis HMP PPKn UPY dan HMPS PPKn UAD) terutama TVOne dan MetroTV, dan yang terakhir yaitu media surat kabar cetak (cenderung hanya diamanfaatkan oleh para aktivis HMP PPKn UPY) terutama Kedaulatan Rakyat dan Kompas. Informasi yang yang paling banyak digali yaitu informasi seputar kasus korupsi yang menjerat para pejabat negara semisal kasus MK, perkembangan politik seputar pemilihan umum (pemilu) 2014 baik pemilu legislatif maupun pemilu presiden dan wakil presiden serta berbagai pemberitaan lain seputar perkembangan kurikulum 2013 dan isu kewajiban PPG, dan pemberitaan yang juga tidak kalah menarik yaitu pemberitaan terkait permasalahan sosial seperti kasus pelecehan seksual yang terjadi di beberapa sekolah inter- nasional di Jakarta. Pemberitaan seputar pemilu 2014 merupakan pemberitaan yang paling banyak diminati oleh para aktivis HMP PKn di Yogyakarta.

Selanjutnya, berakaitan dengan peran media massa sebagai sarana partisipasi politik, maka berdasarkan penelitian yang telah dilaksanakan di HIMA PKnH UNY, HMP PPKn UPY, dan HMPS UAD diperoleh hasil bahwa ternyata pemanfaatan media massa sebagai sarana partisipasi politik para aktivis HMP PKn sebenarnya pernah dilakukan tetapi dapat dikatakan masih belum maksimal. Hal ini dapat dilihat dari hasil observasi, wawancara, dan dokumentasi yang diperoleh selama penelitian ini dilakukan. Ketiga jenis media massa, yaitu media TV, media internet, dan media surat kabar cetak pernah mereka gunakan sebagai sarana partisipasi politik.

Media TV ternyata pernah dimanfaatkan oleh beberapa aktivis HMP PPKN UPY sebagai sarana partisipasi politik. Meskipun masih tehitung jarang, tetapi para aktivis pernah memberikan partisipasi mereka melalui media televisi, yaitu di stasiun TV TVRI. Berbeda dengan media TV yang masih terbatas pemanfaatannya, media internet cenderung lebih banyak digunakan oleh para aktivis HMP PKn di Yogyakarta sebagai sarana partisipasi politik. Berdasarkan hasil penelitian yang telah dilakukan terhadap para aktivis HMP PKn di Yogyakarta diketahui bahwa para aktivis HMP PPKn di Yogyakarta cukup aktif menulis opini di kompasiana.com serta pernah mencoba mengungkapkan berbagai opini atau kritik terhadap kinerja pemerintah, salah satunya dengan meng-up date status melalui facebook dan twitter mereka.

Selain penulisan opini melalui media internet, para aktivis juga mulai aktif menulis di media surat kabar cetak seperti Kompas dan Kedaulatan Rakyat terutama berkaitan dengan pro kontra kurikulum 2013 dan kewajiban PPG bagi para calon pendidik. Sebagian besar aktivis HMP PKn di Yogyakarta pernah melakukannya, tetapi cukup jarang dan bahkkan belum pernah dimuat karena untuk bisa dimuat memerlukan prosedur dan proses seleksi yang sulit. Hal ini 
menyebabkan produktivitas menulis di surat kabar cetak nasional tidak begitu nampak padahal para aktivis cukup aktif menulis. Para aktivis HMP PKn di Yogyakarta mengatakan bahwa aktivitas menulis mereka di surat kabar masih sebatas dimuat di surat kabar kampus. Secara umum tulisan mereka berisikan tentang opini atau kritikan terhadap birokrasi kampus.

Berdasarkan uraian di atas dapat disimpulkan bahwa sebagian besar para aktivis HMP PKn di Yogyakarta telah mampu memanfaatkan media massa sebagai sarana partisipasi politik. Berkaitan dengan jenis media massa yang digunakan, dapat disimpulkan bahwa media internet merupakan media massa yang paling banyak digunakan sebagai sarana partisipasi politik (dimanfaatkan oleh para aktivis HIMA PKnH UNY, HMP PPKn UPY, dan HMPS PPKn UAD) terutama kompasiana.com, selanjutnya yaitu media surat kabar cetak (dimanfaatkan oleh para aktivis HIMA PKnH UNY dan HMP PPKn UPY) terutama Kedaulatan Rakyat, dan terakhir yaitu media TV (dimanfaatkan oleh para aktivis HMP PPKn UPY) yaitu stasiun TV TVRI.

Partisipasi politik para aktivis dalam bentuk penyampaian opini, kritik, maupun pendapat terkait berbagai isu dan permasalahan publik terutama seputar kasus korupsi yang menjerat para pejabat negara semisal kasus MK, seputar pemilihan umum (pemilu) 2014 baik pemilu legislatif maupun pemilu presiden dan wakil presiden, seputar kurikulum 2013 dan isu kewajiban PPG, dan permasalahan sosial seperti kasus pelecehan seksual yang terjadi di beberapa sekolah internasional di Jakarta. Polemik seputar pemilu 2014 merupakan hal yang paling banyak diminati oleh para aktivis HMP PKn di Yogyakarta untuk dikritisi. dapat dikatakan tidak terlalu pasif. Para aktivis pernah melakukannya, hanya saja motivator, intensitas, dan medianya cukup beragam.

Berdasarkan hasil penelitian tentang pemanfaatan media massa oleh para aktivis HMP PKn di Yogyakarta baik sebagai sumber informasi maupun sebagai sarana partisipasi politik tersebut selanjutnya dapat ditarik kesimpulan bahwa peran media yang paling dominan yaitu sebagai sumber informasi. Hal ini dikuatkan oleh fakta bahwa berdasarkan hasil observasi, wawancara, dan dokumentasi selama penelitian ini dilaksanakan cenderung memperlihatkan peran media massa sebagai sumber informasi. Sedangkan peran media massa sebagai sarana partisipasi politik telah mampu ditunjukkan oleh para aktivis HMP PKn di Yogyakarta namun masih cukup terbatas sehingga masih perlu ditingkatkan.

Berdasarkan hasil penelitian tentang peran media massa oleh para aktivis HMP PKn di Yogyakarta baik sebagai sumber informasi maupun sebagai sarana partisipasi politik tersebut selanjutnya dapat ditarik kesimpulan bahwa peran media yang paling dominan yaitu sebagai sumber informasi. Hal ini dikuatkan oleh fakta bahwa berdasarkan hasil observasi, wawancara, dan dokumentasi selama penelitian ini dilaksanakan cenderung memperlihatkan peran media massa sebagai sumber informasi. Sedangkan peran media massa sebagai sarana partisipasi politik telah mampu ditunjukkan oleh para aktivis HMP PKn di Yogyakarta namun masih cukup terbatas sehingga masih perlu ditingkatkan.

Segala bentuk partisipasi politik yang mereka lakukan merupakan bentuk tanggung jawab mereka sebagai warga negara yang memiliki kewajiban untuk turut serta berjuang membawa bangsa dan negara Indonesia menuju arah yang lebih baik. Hal ini didasari pada perasaan ketidakpercayaan mahasiswa terhadap ketidakmampuan pemerintahan yang sedang berkuasa dalam menjalankan roda pemerintahan. Oleh sebab itu, sebagaimana yang diungkapkan Samsuri (2012, p.57), bahwa respon mahasiswa semacam ini tidak boleh dilemahkan, agar tidak membunuh cita-cita demokrasi yang selama ini diusung, sehingga tidak akan memunculkan otoritarianisme yang lahir dari sikap apatisme warga negara. Apabila sikap apatisme telah mengakar kuat pada diri mahasiswa sebagai agent of change atau social controller, maka dapat dipastikan demokrasi juga akan mati.

Hal ini senada dengan yang diungkapkan Thomas (2009, p.189), bahwa keterlibatan 
mahasiswa dalam setiap perubahan tatanan kenegaraan merupakan pilar utama terjaminnya sebuah tatanan kenegaraan yang demokratis. Berkaitan dengan hal ini, menurut CIRCLE sebagaimana yang dikutip oleh Print (2007: 328 ), yang menyatakan bahwa peran sebagai social controller dapat diwujudkan melalui berbagai tindakan partisipasi politik aktif seperti penyampaian pendapat politik melalui berbagai media massa sudah tepat dilakukan oleh para aktivis HMP PKn di Yogyakarta.

Menurut Usman (1999, pp.159-160), partisipasi politik dapat digolongkan menjadi dua macam. Pertama, digolongkan dalam gerakan politik atau gerakan partisan sebab dilakukan karena mobilisasi oleh pihak-pihak tertentu yang kemudian. Kedua, digolongkan dalam gerakan moral atau gerakan partisipan sebab dilakukan atas kesadaran pribadi tanpa mobilisasi yang kemudian. Berkaitan dengan hal ini, secara tegas para aktivis HMP PKn di Yogyakarta membantah bahwa mereka tidak dimobilisasi oleh pihak-pihak manapun. Kesadaran masing-masing pribadi untuk bisa berpartisipasi dengan baik sebagai warga negara akan mengarahkan para aktivis HMP PKn di Yogyakarta untuk menjadi sosok yang kritis terhadap pemerintah, sehingga dapat tergerak untuk melakukan tindakan yang bertujuan untuk memperbaiki birokrasi yang sedang berlangsung.

Merujuk pada teori tersebut, maka dapat disimpulkan bahwa partisipasi politik para aktivis HMP PKn di Yogyakarta tergolong dalam gerakan moral. Partisipasi politik semacam ini memposisikan mahasiswa sebagai kekuatan penggerak perubahan ketika institusi birokrasi dan instutusi politik tidak mampu melakukan peran sesuai tuntutan sektor publik. Partisipasi politik mahasiswa diletakkan untuk menggerakkan dan meluruskan kembali fungsi-fungsi mahasiswa, karena apabila permasalahan politik, sosial, hukum, ekonomi, dan pendidikan tidak segera dipecahkan, rakyat terus tertindas dan menderita. Oleh sebab itu, dalam pandangan ini, posisi mahasiswa berada di luar institusi birokrasi dan di luar institusi politik (partai politik), namun tetap melakukan fungsi kontrol. Pada posisi inilah, mahasiswa berperan sebagai partisipan dan bukan partisan yang bertindak atas nama pihak tertentu semisal partai politik.

Para aktivis HMP PKn di Yogyakarta berupaya menyumbangkan buah pikir bagi kemajuan bangsa melalui tulisan-tulisan mereka yang mereka sampaikan kepada berbagai pihak dengan memanfaatkan berbagai media massa. Melalui tulisan-tulisan mereka yang berisikan tentang opini, kritikan, saran, maupun pendapat terkait berbagai permasalahan publik seperti politik, sosial, hukum, ekonomi, dan perndidikan, mereka berharap dapat melurusan berbagai kebijakan publik yang tidak prorakyat. Dikatakan demikian sebab pada hakikatnya para mahasiswa merupakan penyambung lidah rakyat yang bertugas menyampaikan berbagai aspirasi rakyat agar tercipta keadilan di berbagai sektor, bidang, dan sendi kehidupan berbangsa dan bernegara. Sebagaimana yang pernah dilakukan oleh para aktivis HMP PKn di Yogyakarta. Berkaitan dengan pemilu 2014, para aktivis HMP PKn di Yogyakarta membuat kesepakatan tentang sikap ketidaksetujuan mereka terhadap kegiatan kampanye yang dilakukan di kampus. Persetujuan tersebut mereka realisasikan melalui sebuah petisi yang disampaikan kepada pihak-pihak yang berkepentingan. Perjuangan ini ternyata tidak sia-sia karena mampu mempengaruhi keputusan partai politik dan pihak kampus sehingga bersedia membatalkan rencana kegiatan kampanye di kampus.

Polemik pemilu 2014 menjadi permasalahan yang paling banyak dikritisi oleh para aktivis HMP PKn di Yogyakarta. Hal ini disebabkan karena penelitian ini bertepatan dengan momentum pemilihan legislatif 2014 sehingga perhatian para aktivis HMP PKn di Yogyakarta lebih banyak tertuju pada momentum tersebut. Tidak dapat dipungkiri bahwa pemilihan legislatif yang dilaksanakan pada tahun 2014 masih sarat dengan kecurangan terutama dalam bentuk politik uang. Selain itu, proses rekruitmen calon legislatif juga masih perlu pembenahan sebab rakyat Indonesia membutuhkan figur-figur yang profesional dan bukan 
lahan rekruitmen tenaga kerja. Berbagai kasus korupsi juga menjadi permasalahan yang cukup banyak dikritisi oleh para aktivis HMP PKn di Yogyakarta meskipun tidak sebanyak kritik terhadap polemik pemilu 2014.

Korupsi menjadi masalahan yang tidak henti-hentinya menyita perhatian para aktivis HMP PKn di Yogyakarta. Para aktivis HMP PKn di Yogyakarta menggunkan media massa untuk menyampaikan kekecewaan mereka terhadap berbagai kasus korupsi. Kekecewaan tersebut membawa mahasiswa menuntut agar para koruptor ditindak secara adil bahkan diganjar dengan hukuman mati agar berhenti menyakiti rakyat. Oleh sebab itu, pernyataan Thomas (2009, p.187) yang mengatakan bahwa tugas mahasiswa sebagai social controller merupakan kunci dalam memahami fenomena perhatian mahasiswa terhadap struktur-struktur sosial seperti pemerintah, lembaga keagamaan sentral, dan lain sebagainya menjadi sangat penting. Tanpa memahami struktur pemerintahan dan berbagai kondisi birokrasi yang ada, maka mahasiswa tidak dapat menjalankan tugasnya sebagai social controller yang merujuk pada upaya perbaikan berbagai kebijakan pemerintah yang tidak prorakyat.

Berdasarkan uraian di atas dapat disimpulkan bahwa seluruh aktivis HMP PKn di Yogyakarta baik yang berasal dari HIMA PKnH UNY, HMP PPKn UPY, maupun HMPS PPKn UAD merupakan partisipan. Ideologi kampus tidak berpengaruh terhadap kecenderungan gerakan partisipasi mereka yaitu tipe gerakan moral. Partisipasi politik gerakan moral merupakan upaya warga negara dalam rangka memengaruhi pembuatan keputusan pemerintah. Hal ini dirasa tepat dilakukan oleh mahasiswa sebagai agent of change atau social controller yang bertugas mengkritisi berbagai kebijakan pemerintah yang tidak prorakyat melalui berbagai tindakan, termasuk melalui media massa. Partisipasi gerakan moral dianggap menjadi partisipasi politik yang jauh lebih mampu mempengaruhi keputusan pemerintah dibandingkan partisipasi politik praktis yang hanya dapat dilakukan pada saat-saat tertentu saja semisal pada saat pemilu. Hal ini dikere- nakan partisipasi politik gerakan moral dapat dilakukan kapan saja. Oleh sebab itu, melalui gerakan partisipasi politik tipe ini, para aktivis HMP PKn di Yogyakarta dapat terus berperan aktif sebagai agent of change atau social controller yang memperjuangkan kepentingan bangsa dan negara Indonesia.

Tipe kebudayaan politik ini merupakan suatu bentuk budaya politik yang anggota masyarakatnya telah memiliki pemahaman yang baik mengenai empat dimensi penentu budaya politik. Menurut Almond \& Verba (1989, p.16), dimensi-dimensi yang biasanya menjadi ukuran dalam menentukan budaya politik suatu masyarakat adalah:

Pertama, dilihat dari tingkat pengetahuan umum para aktivis HMP PKn di Yogyakarta mengenai sistem politik negaranya, seperti pengetahuan tentang letak geografis dan konstitusi negara. Pengetahuan umum semacam ini jelas dimiliki oleh para aktivis HMP PKn di Yogyakarta sebab pengetahuan ini merupakan materi dasar yang harus dimiliki oleh para aktivis. Tanpa adaya pengetahuan ini, para aktivis tidak dapat berpartisipasi secara baik.

Kedua, pemahaman masyarakat mengenai struktur dan peran pemerintah dalam membuat kebijakan. Somantri (2001, pp.275276), menyatakan bahwa PKn pada dasarnya mengambil bagian dari isi ilmu politik, yaitu bagian demokrasi politik yang terdiri atas: (1) konteks ide demokrasi, (2) konstitusi negara, (3) inputs sistem poltik, (4) partai politik dan kelompok penekan, (5) lembaga-lembaga pengambil keputusan, (6) pemilihan umum, (7) presiden sebagai kepala negara/administrasi negara, (8) lembaga yudikatif, (9) outputs dari sistem demokrasi politik, (10) kesejahteraan umum dan pertahanan negara, dan (11) perubahan sosial dan demokrasi politik. Kesebelas materi PKn ini wajib diajarkan kepada para mahasiswa pada Program Studi PKn, sehingga para aktivis HMP PKn di Yogyakarta tentu memiliki pengetahuan ini.

Ketiga, pemahaman mengenai penguatan kebijakan yang meliputi masukan opini dari mahasiswa dan media massa kepada pemerintah. Leung \& Print (2002, p.200), mengatakan 
bahwa PKn bertujuan untuk membentuk kepribadian mahasiswa agar menjadi individu yang mampu berpikir kritis, demokratis, bertanggung jawab, setia kepada negara, serta mampu berpartisipasi aktif sebagai warga negara, sehingga mampu membangun hubungan yang baik antara pemerintah dengan warga negara. Agar dapat membangun interaksi antara pemerintah dan warga negara maka diperlukan proses, partisipasi, dan kontribusi dari warga negara terhadap pemerintah, sehingga masyarakat dapat mengoreksi segala kebijakan pemerintah. Hal ini menegaskan bahwa mahasiswa PKn diajarkan tentang pemahaman tentang makna dari interaksi antara pemerintah dan warga negara. Oleh sebab itu, masukan opini dari mahasiswa yang disampaikan melalui berbagai media massa kepada pemerintah merupakan bagian dari interaksi tersebut yang harus dipahami oleh para aktivis HMP PKn di Yogyakarta.

Keempat, sejauh mana partisipasi masyarakat dalam berpolitik dan bernegara, serta sejauh mana pemahamannya mengenai hak dan kewajibannya sebagai warga negara. Berkaitan dengan hal ini, menurut John Patrick sebagaimana yang dikutip Samsuri (2012, p.56), menyatakan bahwa terdapat empat komponen atau ketegori pokok yang hendaknya dipahami bahkan dikuasai oleh para pendidik atau calon pendidik PKn, keempat komponen tersebut, yaitu: (1) pengetahuan kewarganegaraan dan pemerintahan demokratis, (2) kecakapan kognitif dari kewarganegaraan demokratis, (3) kecakapan partisipasi dari kewarganegaraan demoratis, dan (4) keutamaan karakter kewarganegaraan yang demokratis. Print (2009, p.1005), juga mengatakan bahwa warga negara secara tidak langsung diajarkan tentang norma politik, nilai-nilai luhur politik, perilaku politik, kesetiaan pada negara, serta orientasi politik yang harus dipegang teguh oleh setiap warga negara. Hal ini menegaskan bahwa agar dapat berpatisipasi dengan baik, maka mahasiswa harus memiliki pemahaman yang baik tentang hak dan kewajibannya sebagai warga negara. Oleh sebab itu, ketika para aktivis HMP PKn di Yogyakarta telah mampu berpartisipasi de- ngan baik, maka dapat dipastikan bahwa mereka telah memahami hak dan kewajiban mereka sebagai warga negara.

Berdasarkan pemenuhan keempat dimensi yang menjadi ukuran dalam tipe budaya politik tersebut, maka dengan merujuk pada teori Almond \& Verba (1989, pp.16-18) dapat disimpulkan bahwa budaya politik para aktivis HMP PKn di Yogyakarta dapat digolongkan ke dalam tipe Budaya Politik Partisipan. Budaya politik partisipan terlahir dalam masyarakat yang sikap dan orientasi politiknya didominasi oleh karakteristik yang bersifat evaluatif atau yang biasa disebut dengan Orientasi Politik Evaluatif. Tipe kebudayaan politik ini merupakan suatu bentuk budaya politik yang anggota masyarakatnya telah memiliki pemahaman yang baik mengenai empat dimensi penentu budaya politik.

Para aktivis HMP PKn di Yogyakarta telah mampu membuat keputusan, pendapat dan penilaian tentang objek-objek politik yang secara tipikal melibatkan nilai moral yang ada dengan mempertimbangkan berbagai informasi yang diperoleh dengan perasaan yang dimiliki. Hal ini berarti para aktivis HMP PKn di Yogyakarta telah memahami secara mendalam mengenai peran dan kewajiban dirinya dan juga pemerintah yang didasarkan nilai-nilai moral yang dipegang teguh, sehingga mahasiswa tergerak untuk melakukan berbagai tindakan nyata sebagai wujud penerimaan atau penolakan terhadap sebuah kebijakan.

Pada budaya politik ini, para aktivis HMP PKn di Yogyakarta telah memiliki pengetahuan yang memadai mengenai sistem politik secara umum, tentang peran pemerintah dalam membuat kebijakan beserta penguatan, dan telah mampu berpartisipasi aktif dalam proses politik yang berlangsung. Mahasiswa menjadi pribadi yang aktif dalam semua dimensi di atas. Sikap menolak atau menerima terhadap berbagai kebijakan pemerintah telah diwujudkan melalui berbagai tindakan nyata, sehingga tidak hanya sebatas sikap. Para aktivis HMP PKn di Yogyakarta telah berani melakukan sebuah tindakan nyata. Walaupun sebenarnya melakukan sebuah tindakan nyata yang dapat secara 
langsung memberikan efek perubahan kepada orang lain memang tidak mudah, namun para aktivis tetap berusaha untuk melakukan sebuah hal meskipun masih dalam taraf sederhana. Mereka tidak hanya sekedar diam acuh-tak acuh.

Freedman (2006, p.95), menyatakan bahwa Indonesia merupakan negara demokratis yang banyak dipengaruhi oleh karakter partisipatif yang menjiwai kehidupan demokatis bangsa Indonesia itu sendiri. Budaya politik partisipan merupakan budaya politikyang mencoba mengarahkan mahasiswa untuk berperan aktif dalam proses politik yang berlangsung di negaranya. Budaya politik demokratis merupakan budaya politik yang menempatkan rakyat sebagai pemegang kedaulatan tertinggi. Gaffar (2006, p.100) juga menyatakan hal yang sama, bahwa budaya politik demokratis atau budaya partisipasi politik akan sangat mendukung terbentuknya sebuah sistem politik yang demokratik dan stabil yang akan menjadi penopang terwujudnya partisipasi. Sistem politik yang demokratik dan stabil akan mampu meningkatkan partisipasi politik warga negara.

Berdasarkan hasil penelitian sebagaimana yang telah diuraikan sebelumnya, pada dasarnya para aktivis HMP PKn di Yogyakarta merupakan sosok yang cukup aktif berpartisipasi. Meskipun demikian, partisipasi tersebut perlu diperkuat kembali dengan sistem demokrasi yang konsekuen, sehingga partisipasi politik para aktivis HMP PKn di Yogyakarta dapat mengalami peningkatan, agar terwujud budaya politik yang demokratis.

Para aktivis HMP PKn di Yogyakarta telah memanfaatan media massa dalam meningkatkan partisipasi politik, baik sebagai sumber informasi maupun sebagai sarana partisipasi politik meskipun sebenarnya dapat dilakukan secara lebih maksimal, sebab seluruh waktu senggang yang dimiliki oleh para aktivis HMP PKn di Yogyakarta seharusnya dapat dimanfaatkan secara optimal untuk memanfaatkan berbagai media massa baik sebagai sumber informasi maupun sebagai saran partisipasi politik.

Meskipun demikian, hal tersebut telah mampu mengarahkan para aktivis HMP PKn di Yogyakarta pada kecenderungan tipe gerakan dan budaya politik yang unggul. Partisipasi politik para aktivis HMP PKn di Yogyakarta dapat digolongkan ke dalam tipe gerakan moral sebab para aktivis HMP PKn di Yogyakarta secara keseluruhan merupakan partisipan dan bukan partisan. Tipe gerakan moral jauh lebih baik dibandingkan dengan tipe gerakan politik sebab tipe gerakan moral terlahir dari kesadaran diri warga negara dan bukan terlahir dari mobilisasi sebagaimana yang ada pada tipe gerakan politik.

Sedangkan dalam kaitannya dengan budaya politik, partisipasi politik para aktivis HMP PKn di Yogyakarta tergolong pada tipe budaya politik partisipan yang dapat dilihat dari pemenuhan empat dimensi budaya politik yang ada pada tipe budaya politik partisipan. Budaya politik partisipasipan megandung aspek kognitif, afektif, dan psikomotorik, sehingga budaya politik ini merupakan budaya politik yang paling baik dibanding budaya politik subjek yang hanya sebatas sikap saja, apalagi budaya politik parokhial yang hanya sebatas pada pengetahuan saja.

\section{Faktor yang Mendorong Peran Media Mas- sa dalam Meningkatkan Partisipasi Politik para Aktivis HMP PKn di Yogyakarta}

Kemampuan para aktivis HMP PKn di Yogyakarta untuk memanfaatan media massa dalam meningkatkan partisipasi politik ternyata dipengaruhi oleh berbagai faktor.

Pertama, berkaitan dengan kebutuhan perkuliahan. Dosen selalu memotivasi mahasiswa untuk terus menggali berbagai informasi terkait perkembangan isu dan permasalahan politik, sosial, hukum, ekonomi, dan pendidikan dari segala sumber. Dosen juga berusaha membawa berbagai isu dan permasalahan publik yang sedang terjadi tersebut ke dalam kelas. Dosen cenderung memberikan tugas-tugas kuliah yang bersifat kontekstual yang menuntut mahasiswa untuk selalu mengikuti perkembangan informasi. Oleh sebab itu, media massa juga dimanfaatkan untuk mendukung kelengkapan tugas-tugas kuliah seperti pembuatan makalah dan penulisan artikel. Hal ini mam- 
pu memicu kesiapan para mahasiswa terhadap berbagai perkembangan pemberitaan di berbagai media massa.

Kedua, berkaitan dengan kesadaran diri para aktivis sebagai mahasiswa PKn sekaligus sebagai warga negara yang baik. Para aktivis HMP PKn menyadari bahwa mereka sedang menempuh pendidikan pada Program Studi PKn yang berbeda dengan Program Studi yang lain. Program Studi PKn berusaha menuntut mahasiswa untuk mampu bersikap kritis terhadap berbagai isu dan permasalahan publik yang sedang terjadi. Para aktivis menyadari peran mereka sebagai warga negara yang baik yang memiliki tugas sebagai agen perubahan. Agar dalam bersikap sigap terhadap berbagai isu dan permasalahan publik, para mahasiswa harus memiliki pengetahuan dan informasi yang memadai. Oleh sebab itu, media massa sangat mendukung pemenuhan kebutuhan akan informasi tersebut sehingga dapat menentukan sikap dan tindakan yang dinilai paling tepat dalam upaya menyelesaikan berbagai permasalahan tersebut.

Kesadaran untuk berpartisipasi yang ada dalam diri para aktivis HMP PKn di Yogyakarta erat hubungannya dengan berbagai permasalahan publik yang sedang terjadi sehingga mampu mendorong keprihatinan dan kepedulian para aktivis HMP PKn di Yogyakarta untuk melakukan sebuah tindakan nyata. terdapat tiga permasalahan publik utama yang mampu memotivasi para aktivis HMP PKn di Yogyakarta untuk bersikap dan bertindak kritis melalui penyampaian opini di berbagai media massa. Peramsalahan publik tersebut, yaitu: Pertama, kekecewaan terhadap berbagai penyalahgunaan wewenang oleh lembaga legislatif dan yudikatif terutama dalam bentuk tindakan korupsi yang sangat merugikan keuangan negara. Sebagai warga negara, para aktivis merasa sangat kecewa dengan berbagai tindakan korupsi tersebut. Kedua, proses rekruitmen politik yang masih buruk. Para aktivis HMP PKn di Yogyakarta juga mengaitkannya dengan momen pemilu 2014. Sebab, pemilihan umum 2014 merupakan bagian dari proses rekruitmen pejabat legislatif yang masih sarat kecuranagn semisal politik uang. Ketiga, lembaga peradilan yang kurang independen. Para aktivis sangat kecewa dengan penegakan hukum di Indonesia yang belum indenpen karena masih dapat diperjualbelikan. Terdapat banyak sekali permasalahan hukum yang penyelesaiannya tidak memuaskan karena para hakim masih bersedia menerima uang suap terutama permasalahan suap di Mahkamah Konstitusi (MK) yang sangat mengecewakan para aktivis HMP PKn di Yogyakarta sehigga permasalahan ini cukup banyak dikritisi.

\section{Faktor yang Menghambat Peran Media Mas- sa dalam Meningkatkan Partisipasi Politik para Aktivis HMP PKn di Yogyakarta}

Secara umum, para aktivis HMP PKn di Yogyakarta telah mampu menunjukkan pemanfaatan media baik sebagai sumber informasi maupun sebagai sarana partisipasi politik. Motivasi mereka cukup tinggi. Meskipun demikian, tetap dapat dikatakan bahwa kegiatan semacam ini belum maksimal. Berkaitan dengan peran media massa sebagai sarana sumber informasi, para aktivis HMP PKn di Yogyakarta para aktivis HMP PKn di Yogyakarta tidak mengalami kendala. Pihak kampus, pihak jurusan, bahkan HMP PKn sendiri memberikan keleluasaan untuk mengakses berbagai informasi melalui penyediaan berbagai sarana informasi yang dibutuhkan oleh para mahasiswa secara umum dan para aktivis HMP PKn pada khususnya. Media TV, media surat kabar atau koran, dan terutama media internet dapat dengan mudah dimanfaatkan sehingga sangat membantu para mahasiswa untuk memperoleh berbagai informasi yang dibutuhkan.

Berkaitan dengan peran media massa sebagi sarana partisipasi politik ternyata masih terhambat dari segi publikasinya maupun kesempatan untuk terbaca oleh berbagai pihak yang disasar. Alasan keterbatasan dalam pemanfaatan media massa sebagai sarana partisipasi politik cukup beragam. Faktor-faktor yang menghambat peran media massa dalam meningkatkan partisipasi politik para aktivis HMP PKn di Yogyakarta sebagai berikut:

Pertama, kebebasan berpendapat ter- 
nyata belum sepenuhnya dijamin. Kunci pergerakan demokrasi di Indonesia terletak pada kuatnya semangat bangsa Indonesia untuk memperjuangkan terwujudnya negara yang mampu menjunjung tinggi hak-hak rakyat dalam partisipasi politik. Hal ini ternyata justru memberikan rasa takut pada diri para aktivis HMP PKn di Yogyakarta terhadap hukum yang berlaku di Indonesia. Mereka berpendapat bahwa Indonesia merupakan negara yang demokratis namun menurut mereka belum sepenuhnya demokratis karena kebebasan berpendapat belum sepenuhnya dijamin. Tidak mudah melontarkan kritikan terhadap berbagai pihak. Mereka khawatir bahwa tulisan mereka akan merugikan pihak-pihak tertentu sehingga akan membahayakan diri mereka sendiri seperti misalnya tersangkut kasus pencemaran nama baik oleh pihak atau instansi tertentu yang merasa dirugikan. Hal ini menyebakan timbulnya rasa khawatir dalam diri mereka ketika meng-upload atau mengirimkan tulisan mereka ke berbagai media massa.

Kedua, tulisan terus terbaharui sehingga tidak semua tulisan dapat terbaca. Melalui pemanfaatan media televisi, surat kabar, dan internet, maka setiap orang semakin mudah mendapatkan informasi. Kuatnya arus perkembangan komunikasi dan informasi telah menyebabkan penggunakan berbagai media massa mengalami peningkatan. Para aktivis HMP PKn di Yogyakarta menilai bahwa pada era informasi dan komunikasi sekarang ini media massa telah banyak dimanfaatkan oleh khalayak umum. Hal ini menyebabkan mereka berargumen bahwa tulisan para aktivis akan jarang dibaca bahkan mungkin tidak terbaca karena tersusul oleh tulisan-tulisan baru sebagaimana yang terjadi pada media facebook dan twitter yang akan terus terbarui oleh up date-up date yang baru padahal belum sempat dibaca oleh orang lain.

Ketiga, partisipasi melalui kerja nyata di HMP PKn dinilai lebih efektif dibanding menulis opini di media massa. Organisasi-organisasi kemahasiswaan akan mempercepat arus demokrasi. Organisasi kemahasiswaan ini akan mengupayakan berbagai tindakan yang sangat berpihak pada kedaulatan suatu bangsa dan negara sehingga hak-hak rakyat sangat diperhatikan. Berkaitan dengan hal ini, para aktivis menilai bahwa organisasi kemahasiswaan semacam HMP PKn merupakan wadah yang tepat untuk berpartisipasi sebagai mahasiswa. Mahasiswa dapat berpartisipasi dengan baik melalui berbagai program kerja yang telah disusun. Ketika berbagai program kerja tersebut dapat dilaksanakan dengan baik, itulah wujud partisipasi atau kerja nyata mahasiswa sebagai agen perubahan yang lebih efektif. Hal ini menyebabkan para aktivis HMP PKn di Yogyakarta jarang mempublikasikan tulisannya karena mereka merasa telah mampu berpartisipasi melalui berbagai tindakan nyata yang telah terprogram dalam berbagai program HMP PKn di Yogyakarta.

Keempat, padatnya aktivitas kampus. Para aktivis tersebut juga menambahkan bahwa padatnya berbagai aktivitas kampus menyebabkan mereka menjadi kurang berkonsentrasi dengan tulisan mereka. Hal ini dikarenakan mereka masih memiliki aktivitas yang jauh lebih penting dari aktivitas menulis, seperti misalnya mengerjakan tugas-tugas kuliah maupun padatnya aktivitas di HMP PKn itu sendiri yang cukup menyita waktu.

Kelima, proses publikasi yang cukup terbatas dalam media surat kabar cetak. Para aktivis HMP PKn di Yogyakarta memiliki motivasi yang cukup tinggi untuk menulis berbagai opini di media surat kabar cetak. Namun, hal tersebut masih cukup sulit direalisasikan karena terbentur oleh proses publikasi yang cukup sulit. Hal ini menyebabkan tulisan para aktivis HMP PKn di Yogyakarta hanya menjadi koleksi pribadi saja dan belum banyak yang terpublikasi melalui media surat kabar cetak. Oleh sebab itu, pembaca cukup jarang menemukan tulisan-tulisan para aktivis HMP PKn di Yogyakarta di berbagai surat kabar, padahal mereka memiliki banyak tulisan yang diharapkan dapat terpublikasikan dan dibaca oleh berbagai pihak.

\section{SIMPULAN}

Berdasarkan hasil penelitian dan pem- 
bahasannya sebagaimana yang telah diuraikan sebelumnya, selanjutnya dapat ditarik kesimpulan bahwa:

Pertama, peran media massa baik sebagai sumber informasi maupun sebagai sarana partisipasi politik dalam meningkatkan partisipasi politik telah mampu ditunjukkan oleh para aktivis HMP PKn di Yogyakarta. Media internet menjadi media massa yang paling dominan digunakan sebagai sumber informasi maupun sebagai sarana partisipasi politik oleh para aktivis HMP PKn di Yogyakarta. Peran media massa sebagai sumber informasi lebih dominan dibanding peran media massa sebagai sarana partisipasi politik, sebab peran media massa sebagai sumber informasi dapat ditunjukkan oleh para aktivis HMP PKn di Yogyakarta tanpa hambatan. Hal ini berbeda dengan peran media massa sebagai sarana partisipasi politik yang dinilai kurang maksimal karena masih mengalami beberapa hambatan. Peran media massa baik sebagai sumber informasi maupun sebagai sarana partisipasi politik yang telah ditunjukkan oleh para aktivis HMP PKn di Yogyakarta dalam meningkatkan partisipasi politik dapat digolongkan dalam tipe gerakan moral dan tipe budaya politik partisipan.

Kedua, faktor yang mendorong peran media massa baik sebagai sebagai sumber informasi maupun sebagai sarana partisipasi politik dalam meningkatkan partisipasi politik para aktivis HMP PKn di Yogyakarta, yaitu: kebutuhan perkuliahan dan kesadaran diri para aktivis sebagai mahasiswa PKn sekaligus sebagai warga negara yang baik.

Ketiga, peran media massa sebagai sumber informasi dalam meningkatkan partisipasi politik para aktivis HMP PKn di Yogyakarta dapat dikatakan tidak mengalami hambatan sebab aktifitas ini sangat didukung oleh pihak kampus, jurusan, dan HMP PKn itu sendiri dengan menyediakan berbagai fasilitas yang sangat mendukung aktifitas ini. Sedangkan dalam kaitannya dengan peran media massa sebagai sarana partisipasi politik, para aktivis HMP PKn di Yogyakarta cukup aktif dalam menulis, namun dalam kenyataannya masih mengalami kesulitan dalam hal publikasi oleh media massa dan tidak semua tulisan tersebut terbaca oleh berbagai pihak yang disasar, sehingga tulisan-tulisan tersebut masih sebatas sebagai koleksi pribadi saja. Faktor penghambat tersebut, meliputi: kebebasan berpendapat yang belum sepenuhnya dijamin, tulisan terus terbaharui sehingga tidak semua tulisan dapat terbaca, partisipasi melalui kerja nyata di HMP PKn dinilai lebih efektif dibanding menulis opini di media massa, padatnya aktivitas kampus, dan proses publikasi yang cukup terbatas dalam media surat kabar cetak atau koran.

\section{Saran}

Berdasarkan kesimpulan di atas, selanjutnya dapat dikemukakan beberapa saran, yaitu:

Pertama, Indonesia merupakan negara demokratis, namun para aktivis HMP PKn di Yogyakarta menilai bahwa Indonesia belum sepenuhnya menjunjung tinggi kebebasan dalam hal berpendapat. Oleh sebab itu, hendaknya pemerintah memberikan jaminan yang lebih pasti dalam hal hak mengemukakan pendapat, sehingga kemampuan bependapat para aktivis HMP PKn di Yogyakarta tidak terbentengi atau terkekang oleh hukum yang dinilai tidak pasti.

Kedua, Peran media massa sebagai sarana partisipasi politik masih cukup terbatasi oleh adanya proses publikasi yang cukup rumit, terutama terjadi pada media massa cetak. Padahal para aktivis HMP PKn di Yogyakarta cukup berminat memanfaatkan media massa jenis ini. Akibat prosedur publikasi yang rumit, para aktivis HMP PKn di Yogyakarta menjadi kurang berminat untuk mempublikasikan tulisan mereka. Oleh sebab itu, agar tidak membatasi kebebasan berpendapat para aktivis HMP PKn di Yogyakarta, hendaknya pihak media massa mampu bersikap bijaksana, sehingga mampu memotivasi para aktivis HMP PKn di Yogyakarta untuk terus menulis dan menuangkan pemikiran-pemikiran mereka bagi kemajuan bangsa dan negara Indonesia.

Ketiga, Para aktivis HMP PKn di Yogyakarta hendaknya mampu mengisi waktu luang yang mereka miliki dengan sebaik mungkin. Para aktivis HMP PKn di Yogyakarta harus 
mampu mengisinya dengan berbagai kegiatan positif yang dapat mendukung tugas mereka sebagai mahasiswa. Mahasiswa merupakan agen perubahan yang memiliki kewajiban sebagai pembawa perubahan bagi bangsa dan negara menuju arah yang lebih baik. Mahasiswa harus terus berusaha untuk dapat berpartisipasi dalam berbagai aktivitas termasuk pemanfaatan media massa sebagai sarana partisipasi politik untuk meningkatkan tingkat partisipasi politik, sehingga mahasiswa mampu melaksanakan peran sebagai agen perubahan.

\section{UCAPAN TERIMA KASIH}

Terima kasih kami ucapkan kepada semua pihak yang telah membantu. Terima kasih selanjutnya kepada tim redaksi jurna yang telah memuat artikel kami. Semoga penelitian ini memberi banyak manfaat bagi dunia pendidikan dan ilmu pengetahuan.

\section{DAFTAR PUSTAKA}

Almond, G.A. \& Verba, S. (1989). The civic culture: political attitudes and democracy in five nations. London: Sage Publications.

Creswell, J.W. (2012). Research design; pendekatan kualitatif, kuantitatif, dan mixed. (Terjemahan Achmad Fawaid). Yogyakarta: Pustaka Pelajar.

Freedman, A.L. (2006). Political change and consolidation: democracy's rocky road in Thailand, Indonesia, South Korea, and Malaysia. New York: Palgrave Macmillan.Gaffar, Affan. (2006). Politik Indonesia; transisi menuju demokrasi. Yogyakarta: Pustaka Pelajar.

Gazali, Effendi. (2004). Interaksi politik dan media: dari komunikasi politik ke politik komunikasi. Jurnal Ilmu Sosial dan Ilmu Politik, Vol. 8 No. 1, Juli, pp. 53-73.

Junaedi, Fajar. (2013). Komunikasi politik: teori, aplikasi, dan strategi di Indonesia. Yogyakarta: Buku Litera.

Leung, Y.M \& Print, M. (2002). Nationalistic ed- ucation as the focus for civics and citizenship education; the case of Hong Kong. Asia Pacific Education Review, Vol. 3, No. 2, pp. 197-209.

Lubis, Mochtar. (2013). Manusia Indonesia. Jakarta: Yayasan Pustaka Obor Indonesia.

Matulessy, Andik. (2008). Model kausal partisipasi politik aktivis gerakan mahasiswa. $\mathrm{Di}$ sertasi, Universitas Gajah Mada, Yogyakarta.

Miles, M.B. \& Huberman, A.M. (1994). Qualitative data analysis. London: Sage Publications, Inc.

Print, M. (2007). Citizenship education and youth participation in democracy. British Journal of Educational Studies, Vol. 55, No. 3, September, pp. 325-345.

. (2009). Teaching about political and social values. Saha, L.J \& Dworkin, A.G (eds). International Handbook of Research on Teachers and Teaching. Springer Science \& Business Media LLC, pp. 1001-1014.

Republik Indonesia. (1945). Undang-Undang Dasar Republik Indonesia Tahun 1945.

Samsuri. (2012). Pendidikan karakter warga negara: kritik pembangunan karakter bangsa. Surakarta: Pustaka Hanif.

Somantri, M. Nu'man. (2001). Menggagas pembaharuan Pendidikan IPS. Bandung: Remadja Rosda Karya.

Sorensen, G. (2003). Demokrasi dan demokratisasi. (Terjemahan I. Made Krisna). Yogyakarta: Pustaka Pelajar.

Thomas, N. (2009). Children, politics, and communication: participation at the margins. Great Britain: The Policy Press.

Usman, Sunyoto. (1999). Arah gerakan mahasiswa: gerakan politik ataukah gerakan moral? Jurnal Ilmu Sosial dan Ilmu Politik, Vol. 3, No. 2, November, pp.146-163.

Yuniati, Yenni. (2002). Pengaruh berita di surat kabar terhadap persepsi mahasiswa tentang politik. Jurnal Mediator, Vol. 3, No. 1, pp. 79-95. 